\title{
Tidewater glacier beds: insights from iceberg debris in Kongsfjorden, Svalbard
}

\author{
Neil F. Glasser, Michael J. Hambrey \\ Centre for Glaciology, Institute of Geography and Earth Sciences, University of Wales, Aberystwyth Sr23 3DB, Ceredigion, Wales
}

\begin{abstract}
The sediment in icebergs offers an opportunity to sample the otherwise inaccessible beds of modern tidewater glaciers. This paper presents a discussion of the benefits and problems of using iceberg debris to make inferences about the nature of the beds of modern tidewater glaciers. As an example, we present data obtained from icebergs calved from fast-flowing tidewater glaciers in Kongsfjorden, Svalbard. Sediment samples obtained from 12 icebergs show that clast-rich muddy diamicton is the dominant facies, although muddy gravel and mud are also present in some debris layers. Sediment texture and clast-shape analyses indicate that most debris in the icebergs is of basal origin. Micromorphological analyses of thin sections of the diamicton also indicate pervasive deformation of the sediment. Although individual icebergs only represent small samples of the bed of a tidewater glacier, and problems remain in linking iceberg sediments to their precalving transport history beneath the glacier, this method provides a potentially fruitful way of linking sediments to glacier dynamics.
\end{abstract}

\section{INTRODUCTION}

The inaccessibility of most glacier beds hinders detailed studies of the sedimentological and rheological properties of modern subglacial sediments. The nature of modern glacier beds can only be determined by obtaining samples from deep boreholes (Tulaczyk and others, 1998), from geophysical methods (Anandakrishnan and others, 1998; Bell and others, 1998; Gades and others, 2000), by simulation in the laboratory (Iverson and others, 1996, 1997, 1998) and from theoretical modelling experiments (Alley and others, 1987a; Boulton and Hindmarsh 1987; Kamb, 1991). Determining the precise properties of these sediments is, however, critical to understanding subglacial sediment deformation because the behaviour of subglacial sediment greatly influences glacier motion (Alley and others, 1986, 1987b; Blankenship and others, 1986). One potentially fruitful method of investigating the nature of subglacial sediments that has yet to be fully explored is the idea that the inaccessible bed of tidewater glaciers might be sampled by examining the nature of the debris contained in icebergs. In this paper we: (l) describe the methods that can be used to sample icebergs in order to characterize the nature of debris transported into the fjord environment; (2) present data on the sedimentary characteristics of icebergs collected from a northwest Svalbard fjord as a case-study; and (3) discuss the benefits and problems of this technique for establishing the nature of the bed beneath the tidewater glaciers that produce these icebergs.

\section{SAMPLING ICEBERGS IN THE FJORD ENVIRON- MENT}

There are two principal methods that can be used to sample intact the debris in icebergs calved by tidewater glaciers. The first of these is to obtain samples from floating icebergs in open water that can be approached safely by boat (Hunter and others, 1996; Ashley and Smith, 2000). Samples obtained in this way can be used to infer the volumes of ice-rafted sediment and to calculate the sediment fluxes transported by icebergs (Powell and Molnia, 1989; Hunter and others, 1996). However, icebergs approached in this way are far from ideal for sedimentological studies since it is neither practical nor safe to board the iceberg to undertake detailed sedimentary descriptions or sample collection. A second method is to study those icebergs in fjords or lakes that are frozen into place by seasonal lake or sea ice. The advantage of this method is that icebergs can be approached safely and therefore used for detailed sedimentary descriptions and sampling. Travel between individual icebergs is also facilitated across the ice on ski or by skidoo, allowing a large number of icebergs to be visited relatively quickly. Studies of iceberg sedimentation are possible by submersible remotely operated vehicles (ROVs), but these can only be used beneath the surface of a fjord or lake (e.g. to study sedimentary processes at the grounding line), where the original iceberg/debris structure has been lost (Dowdeswell and Powell, 1996). Traditional coring methods and sediment traps can also be used to investigate sedimentation in iceberg-dominated depositional settings, but again these provide little information about the nature of the debris in the icebergs prior to reworking in the water column. In this paper we present sedimentary observations obtained from icebergs frozen by sea ice in a Svalbard fjord and illustrate how his method can provide insight into the dynamics of the glacier that calved the icebergs.

\section{APPLICATION OF THE TEGHNIQUE: A-GASE STUDY FROM SVALBARD}

\section{Field area}

The Svalbard archipelago spans an area from $77^{\circ} \mathrm{N}$ to $80^{\circ} \mathrm{N}$, is currently $60 \%$ glacierized (Hagen and others, 1993) and is 


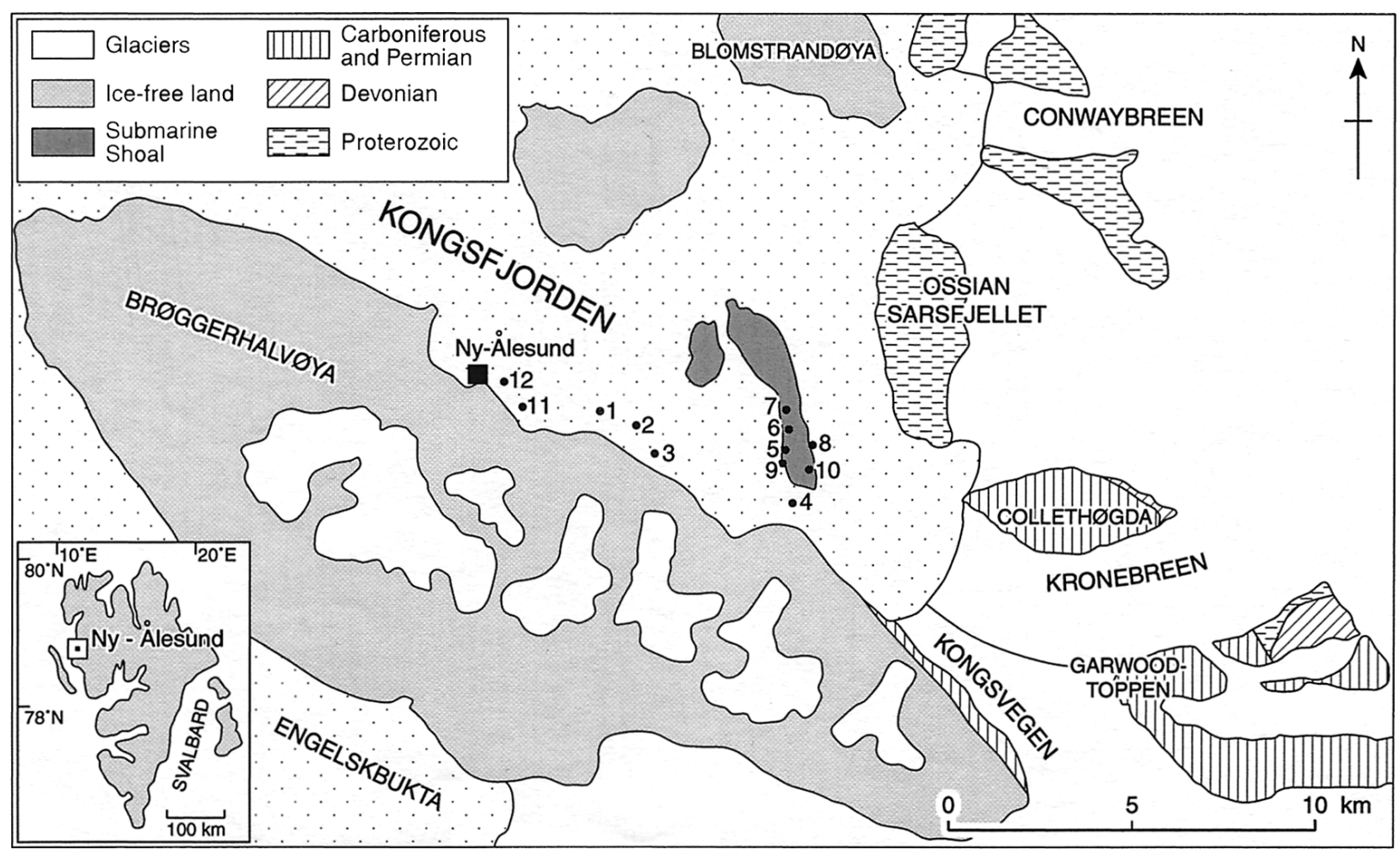

Fig. 1. Location map of Kongsfjorden, showing major tidewater glacier termini and the position of the icebergs sampled. Simplified bedrock geology in the catchments of the glaciers is taken from Hjelle (1993). The Proterozoic rocks consist of schist, psammite and marble; the Devonian rocks are sandstone and siltstone; and the Carboniferous and Permian rocks consist of sandstones, limestone and chert.

dominated by a maritime Arctic climate. The data presented in this paper are from Kongsfjorden, one of the large fjords (26 km long, $8 \mathrm{~km}$ wide, maximum water depth of $428 \mathrm{~m}$ ) that dissect the northwest Spitsbergen coast (Fig. 1). Some $78 \%$ by area of the fjord drainage basin is glacierized, of which the greater proportion $(94 \%$ by area) comprises tidewater glaciers. Sea ice is uncommon in the open fjord in most years, but a stable sea-ice cover often develops around the edges and inner areas of the fjord (Elverhøi, 1984; Ito and Kudoh, 1997). The principal glaciers that supply sediment to the fjord are Kronebreen, Conwaybreen and Blomstrandbreen, all of which reach the sea and calve icebergs (Fig. 1). Kronebreen is divided by Colletthøgda to form two separate tidewater calving fronts in Kongsfjorden and is particularly active, with measured centre-line velocities of $700-800 \mathrm{~m} \mathrm{a}^{-1}$ (Melvold, 1992). Although reliable quantitative data are lacking for the other calving glaciers in Kongsfjorden, a calving rate of $0.25 \mathrm{~km}^{3}$ $\mathrm{a}^{-1}$ has been calculated for Kronebreen (Lefauconnier and others, 1994). Tidewater calving in Kongsfjorden is characterized by the production of numerous small ( $<10 \mathrm{~m}$ wide) icebergs (Dowdeswell and Dowdeswell, 1989; Dowdeswell and Forsberg, 1992).

Like many other glaciers in Svalbard, the glaciers of the Kongsfjorden area are in recession. Kronebreen is receding at rates of between zero and $300 \mathrm{~m} \mathrm{a}^{-1}$, with an average of $200 \mathrm{~m} \mathrm{a}^{-1}$ (Lefauconnier and others, 1994). Exposed bedrock geology in the hinterland of the main branch of Kronebreen (south) is primarily Devonian sandstone and siltstone in the upper part, and Permo-Carboniferous limestone and chert in the lower reaches (Harland, 1997). The true right bank of Kronebreen Central comprises Proterozoic schist, psammite and marble (Fig. 1). The other tidewater glaciers also flow mainly over Proterozoic metamorphic rocks. These geological data allow the provenance of clasts, and thus the source glacier of the icebergs, to be constrained.

\section{Methods}

Twelve upturned debris-rich icebergs (referred to as icebergs KF01-KF12) were examined and sampled in spring 1999, at a time when the sea ice in Kongsfjorden was frozen fast (Fig. 2a). The icebergs were frozen into position in February 1999 during sea-ice formation and, at the time of sampling, the sea ice was $0.5-0.7 \mathrm{~m}$ thick. The position of the icebergs within the fjord was determined with a handheld satellite global positioning system (GPS) (Garmin GPS-45). Descriptions of sediment facies are based on the Hambrey (1994) modification of the classification proposed by Moncrieff (1989). Ice-debris facies were characterized in the laboratory by measurement of particle shape, including for each clast the dimensions of the three orthogonal axes; the clast roundness on a modified Powers (1953) scale; and clast lithology. These data were analyzed using the approach of Benn and Ballantyne (1994) in which the RA index ( $\%$ of angular and very angular clasts) is plotted against the $\mathrm{C} 40$ index ( $\%$ of clasts with $c / a$ axial ratio $\leq 0.4$ ) on a covariant plot. This method has been shown to provide good discrimination between glacial facies in the high-Arctic environment (Bennett and others, 1997). Clasts were also analyzed for lithology to determine their provenance and potential transport paths through the glaciers.

Matrix samples of each of the ice-debris facies were collected for particle-size analysis, involving dry sieving of the coarse fraction (gravel and sand) and analysis of the fine fraction (silt and clay) using a SediGraph 5000 D Particlesize Analyzer. Sorting coefficients for the matrix samples were calculated using the statistical measure (D84-D16)/2. Ice samples were taken for detailed description of crystal structure and ice-debris structures in the laboratory, where positive temperatures allowed etching-out of crystal boundaries. Two impregnated thin sections were made of the 

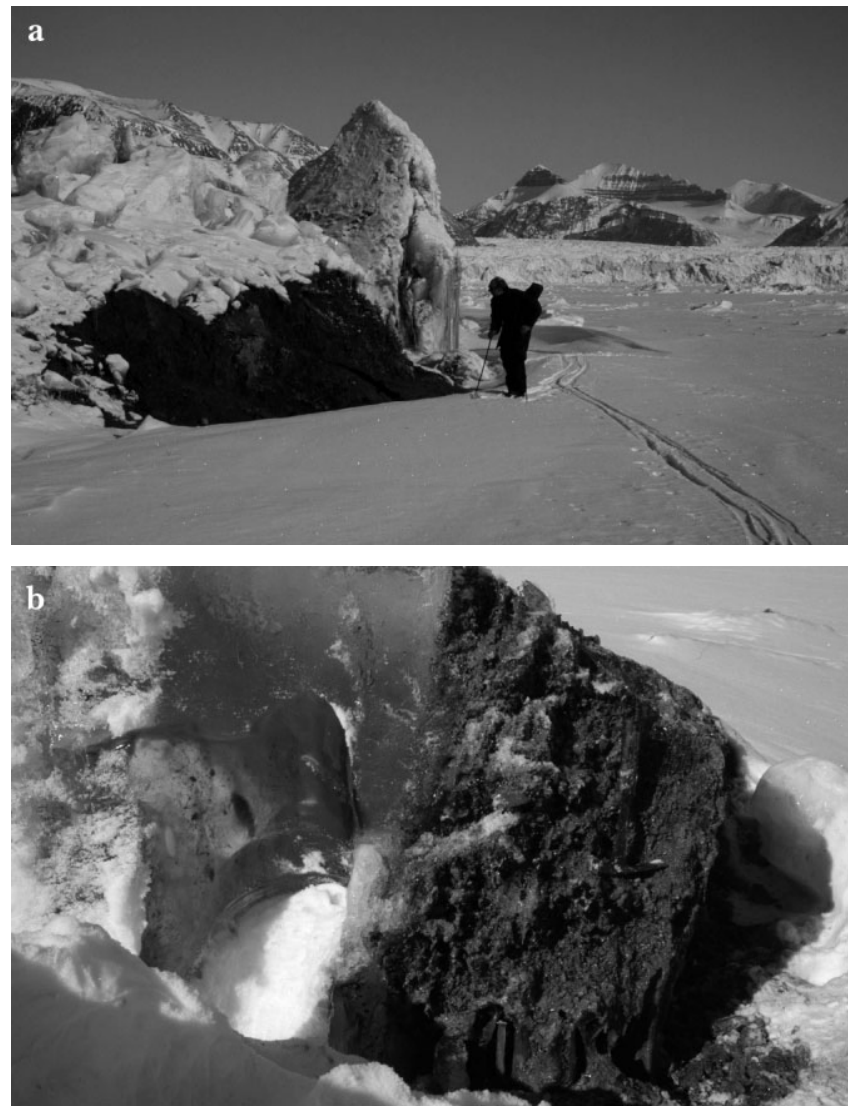

Fig. 2. (a) Photograph of debris in iceberg KF06 in Kongsfjorden, showing debris melting out of the iceberg and streaking the surface below. The tidewater front of Kronebreen can be seen in the background. (b) Close-up of debris in iceberg KF02. Note the sharp contact between the coarse clear ice (left) and the debris layer (right). The debris layer is about $0.4 m$ thick.

debris layer in one of the icebergs (KF07) in order to examine in detail the microstructures in the sediment. Recent developments in thin-section ("micromorphological") analysis of tills have provided new insights concerning the movement of particles within a deforming bed. According to Van der Meer (1997), particles in a deforming bed are subject to two types of movement: (i) planar displacements, which are reflected by the shape of intraclasts and discrete shears; and (ii) rotation, which is indicated by rounded intraclasts, matrix concentrations and matrix reorientations in relation to coarse particles; rotational structures have been termed galaxy or turbate structures, and comprise a nucleus of a grain surrounded by a spiral of finer grains. Using a structural geological approach, Van der Wateren (1998) has recognized a variety of structures indicative of simple shear in the deforming bed, including cleavages, transposed foliations and sheath folds. Further evidence of subglacial shearing is in the form of fractured grains observable in thin section (Hiemstra and Van der Meer, 1997).

\section{Results}

All 12 icebergs possessed a prominent layered structure comprising different types of ice and debris-bearing horizons (Table 1). In all icebergs except three (KF02, KF10, $\mathrm{KF} 12$ ), the sediment was a clast-rich muddy or sandy diamicton. In icebergs KF10 and KF12, only mud was present, and in iceberg KF02 the sediment was muddy gravel (Fig. 2b). Debris layers ranged from being entirely composed of sediment with no interstitial ice, through sharply defined, debris-rich ice layers, to ice layers in which the debris was sparsely disseminated. Folding on the sub-metre scale was also evident. The most common lithologies in the iceberg debris included sandstone, chert, cherty limestone and limestone, siltstone, schist/psammite, quartzite and vein quartz, with minor microgranite, gneiss and marble (Table 1). Most samples contained a distinctive red sandstone and siltstone of Carboniferous and Devonian age, which originate from the Kronebreen catchment (Fig. 1).

Clast shapes within the diamicton facies show a degree of clustering on an RA/C40 plot but are distinct from those in the muddy gravel facies (Fig. 3). In general, clast shapes show a tendency towards subangular and subrounded classes (Table 2). Striated and faceted clasts were present in all those icebergs that contain sediment in the gravel fraction, although the proportion varies between individual icebergs (Table 1). Iceberg KF07 contained an exceptionally thick $(0.3-1 \mathrm{~m})$, well-preserved debris layer, which was in sharp, slightly folded contact with coarse clear ice, with about $1 \mathrm{~m}^{2}$ of its planar basal surface exposed. This surface was covered by "slickensides" (representing the imprint of striations or an interface within the till) and grooved (Fig. 4a). These linear grooves have a uniform orientation and pervaded the entire surface. They were crossed by a sinuous groove about $0.01 \mathrm{~m}$ wide, and up to $0.05 \mathrm{~m}$ deep, with small "levees" on either side (Fig. 4b). A patch of striated surface, measuring about $0.25 \mathrm{~m}$ by $0.3 \mathrm{~m}$, was brecciated (Fig. $4 \mathrm{~b}$ ). The diamicton was dry, ice-free and fractured, with a friable, open-work texture and a planar fabric. Matrix samples from the diamicton facies show high proportions of sand in comparison with the silt and clay fractions (KF01-KF1l, Fig. 5). Calculated sorting coefficients for the diamicton and muddy-gravel matrix samples are 2.63-3.14 (very poorly sorted). The matrix sample from the mud facies is, by comparison, relatively rich in silt and clay. The calculated sorting coefficient for the mud facies sample is 1.42 (poorly sorted). Overall, the particlesize determinations indicate that the diamicton facies are composed of a relatively sandy matrix.

Two thin sections of the diamicton from iceberg KF07 were made in the original vertical plane, one parallel and one normal to the ice-flow direction, as indicated by reference to the slickensides on one surface. A variety of deformational features were evident in the flow-parallel thin section. In order of formation, they are:

(i) Well-developed "galaxies" (Van der Meer, 1997) of subangular and subrounded silt grains forming rings or partial rings around sand-sized and larger grains (Fig. 6a).

(ii) A pervasive fabric of variable strength observable both in hand specimen and under the microscope, defined by the diffuse alignment of inequant particles, especially muscovite, and less commonly quartz and small pebblesized clasts. This fabric is equivalent to the S-cleavage of Van der Wateren (1998) observable in basal tills.

(iii) Numerous chipped and broken grains of sand and larger-sized grains (Hiemstra and Van der Meer, 1997) (Fig. 6b).

(iv) A set of irregular anastomosing open fractures parallel to the aligned fabric in (ii).

(v) Several sets of open fractures unrelated to the pervasive structure in (ii). 
Table 1. Principal characteristics of the icebergs and associated debris in Kongsfjorden. Clast lithologies are based on samples of 50 clasts: C, chert; CL, cherty limestone; SP, schist/psammite; L, limestone; SA, sandstone; VQ vein quartz; Q quartz; SI, siltstone; $M G$, microgranite; $G$, gneiss; $M A$, marble; $O$, others

\begin{tabular}{|c|c|c|c|c|c|c|c|c|c|c|c|c|c|c|c|c|c|}
\hline Iceberg & $\begin{array}{l}\text { Dimen- } \\
\text { sions }^{*}\end{array}$ & Iceberg/debris structure & Sediment facies & \multicolumn{12}{|c|}{ Dominant clast lithologies (\%) } & $\begin{array}{l}\% \\
\text { Striated } \\
\text { clasts }\end{array}$ & $\begin{array}{l}\% \\
\text { Faceted } \\
\text { clasts }\end{array}$ \\
\hline KF01 & $1.5 \times 6$ & $\begin{array}{l}0.13 \text { m clearly defined ice-free debris layer, inter- } \\
\text { stratified with coarse bubbly ice and coarse clear } \\
\text { ice with mud clots }\end{array}$ & $\begin{array}{l}\text { Clast-rich muddy } \\
\text { diamicton }\end{array}$ & 22 & 20 & 20 & 16 & 10 & 10 & - & - & - & - & - & 2 & 24 & 24 \\
\hline KF02 & $2 \times 8$ & $\begin{array}{l}0.4 \mathrm{~m} \text { debris layer comprising disseminated gravel; } \\
\text { sharp contact with coarse clear ice containing } \\
\text { disseminated mud }\end{array}$ & Muddy gravel & 12 & 46 & 14 & 8 & - & - & 4 & - & - & - & - & 10 & 5 & 8 \\
\hline KF03 & $1.5 \times 6$ & $\begin{array}{l}0.03 \mathrm{~m} \text { debris-rich ice layer bounded by coarse } \\
\text { clear ice }\end{array}$ & $\begin{array}{l}\text { Clast-rich muddy } \\
\text { diamicton }\end{array}$ & 18 & 18 & 32 & 6 & 10 & - & - & 8 & - & - & - & 8 & 12 & 10 \\
\hline KF04 & $3 \times 12$ & $\begin{array}{l}0.02-0.03 \mathrm{~m} \text { mud layers (disseminated in ice or } \\
\text { containing no ice); folded with coarse clear ice }\end{array}$ & $\begin{array}{l}\text { Clast-poor muddy } \\
\text { diamicton }\end{array}$ & 28 & 10 & 18 & - & 16 & - & - & 10 & 10 & - & - & 8 & 18 & 5 \\
\hline KF05 & $2 \times 15$ & $\begin{array}{l}0.3 \mathrm{~m} \text { ice--poor debris layer in sharp contact with } \\
\text { clear ice }\end{array}$ & $\begin{array}{l}\text { Clast-rich muddy } \\
\text { diamicton }\end{array}$ & 24 & - & 64 & - & - & - & - & - & - & 6 & - & 6 & 9 & 4 \\
\hline KF07 & $6 \times 60$ & $\begin{array}{l}0.3-1 \mathrm{~m} \text { diamicton layer with grooves, slicken- } \\
\text { sides and basal brecciation on upturned base; in } \\
\text { contact with coarse clear ice }\end{array}$ & $\begin{array}{l}\text { Clast-rich sandy } \\
\text { diamicton }\end{array}$ & 24 & 14 & 12 & 20 & - & 6 & 8 & - & - & - & - & 16 & 55 & 30 \\
\hline KF08 & $5 \times 100$ & $\begin{array}{l}\text { Diffuse } 0.1 \mathrm{~m} \text { wide zone of disseminated mud to } \\
\text { cobbles and clear ice; folded }\end{array}$ & $\begin{array}{l}\text { Clast-rich muddy } \\
\text { diamicton }\end{array}$ & 8 & - & 6 & - & 64 & - & - & 14 & - & - & - & 8 & 48 & 30 \\
\hline KF09 & $3 \times 30$ & $\begin{array}{l}\text { Two } 0.05 \mathrm{~m} \text { debris-rich ice layers interstratified } \\
\text { with bubbly ice }\end{array}$ & $\begin{array}{l}\text { Clast-rich muddy } \\
\text { diamicton }\end{array}$ & 20 & - & 26 & 16 & 4 & 6 & - & - & - & - & 18 & 10 & 44 & 20 \\
\hline KF10 & $2 \times 30$ & $\begin{array}{l}\text { Sand and mud, disseminated in } 0.2 \mathrm{~m} \text { ice layer; } \\
\text { bounded by coarse clear ice }\end{array}$ & Sand and mud & - & - & - & - & - & - & - & - & - & - & - & - & - & - \\
\hline KF11 & $1.5 \times 5$ & $\begin{array}{l}\text { Coarse bubbly, coarse clear and fine--grained ice } \\
\text { with disseminated mud in } 0.1-0.2 \mathrm{~m} \text { layers; } \\
\text { diffuse boundaries }\end{array}$ & $\begin{array}{l}\text { Clast-rich muddy } \\
\text { diamicton }\end{array}$ & - & 10 & - & 16 & 46 & - & - & 22 & - & - & - & 6 & 38 & 21 \\
\hline $\mathrm{KF} 12$ & $1.5 \times 3$ & $\begin{array}{l}0.03 \text { m coarse bubbly ice layer with disseminated } \\
\text { mud, bounded by clean bubbly ice }\end{array}$ & Mud & - & - & - & - & - & - & - & - & - & - & - & - & - & - \\
\hline
\end{tabular}

*Approximate dimensions above sea-ice surface: height and length in metres.

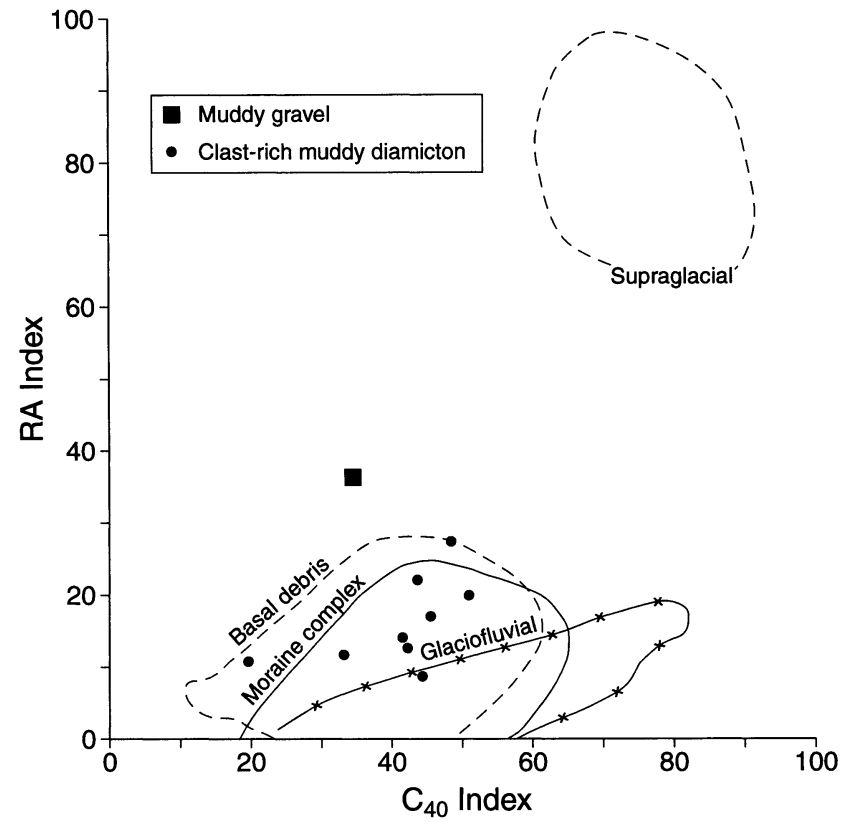

Fig. 3. Covariant plots of the RA index (\% of angular and very angular clasts) against the C40 index (\% of clasts with c/a axial ratio $\leq 0.4)$ for clast-shape data obtained from debris-rich icebergs in Kongsfjorden. Each symbol represents a sample of 50 clasts. The subglacial, supraglacial and glaciofluvial facies envelopes are from Bennett and others (1997). The morainecomplex envelope contains 44 samples of clasts in diamicton emplaced on land by the 1948 surge of the Kongsvegen/Kronebreen tidewater glacier (Bennett and others, 1999).
In the transverse section, the same structures are evident, except for the pervasive aligned fabric and associated fractures. Although on a microscopic scale there are zones of aligned grains, these are inconsistent on the scale of the whole specimen.

\section{Interpretation}

Sedimentary characteristics of the iceberg debris

The iceberg debris in Kongsfjorden is predominantly a clast-poor or clast-rich diamicton, interpreted here as basal glacial sediment on the basis of the sediment texture (predominantly diamicton), clast shape (predominantly suban-

Table 2. Clast-shape data (in \%) for samples of 50 clasts from each of the debris-rich icebergs (VA, very angular; $A$, angular; SA, subangular; SR, subrounded; $R$, rounded; WR, well rounded)

\begin{tabular}{llrrrrr}
\hline Sample No. & VA & $A$ & $S A$ & $S R$ & $R$ & $W R$ \\
\hline KF01 & 6 & 14 & 32 & 44 & 4 & 0 \\
KF02 & 2 & 34 & 12 & 44 & 8 & 0 \\
KF03 & 2 & 22 & 22 & 46 & 8 & 0 \\
KF04 & 0 & 16 & 36 & 40 & 8 & 0 \\
KF05 & 2 & 34 & 40 & 24 & 0 & 0 \\
KF06 & 0 & 16 & 40 & 44 & 0 & 0 \\
KF07 & 0 & 12 & 16 & 48 & 18 & 6 \\
KF08 & 0 & 12 & 28 & 58 & 2 & 0 \\
KF09 & 4 & 6 & 26 & 42 & 22 & 0 \\
KF11 & 2 & 16 & 28 & 52 & 2 & 0 \\
& & & & & & \\
\hline
\end{tabular}



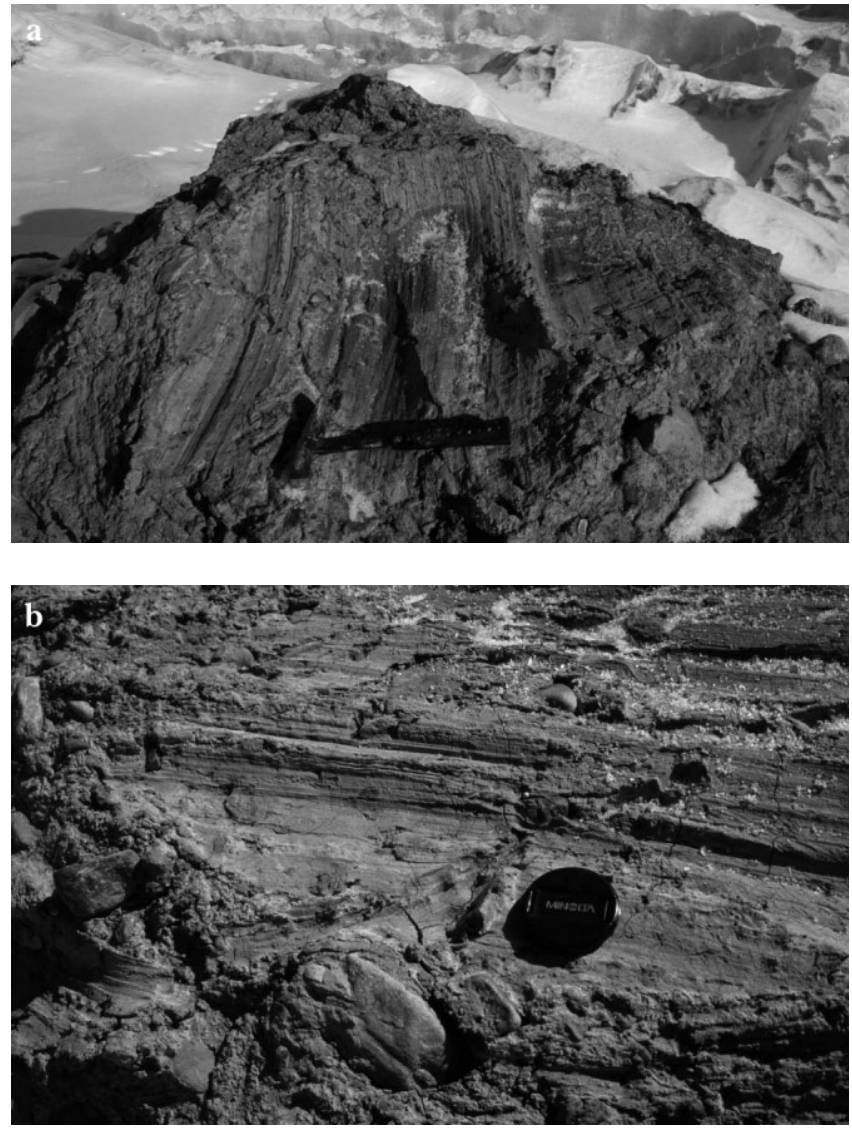

Fig. 4. Iceberg KF07 displaying the nature of part of the bed beneath Kronebreen. (a) Close-up of the iceberg showing slickensides and grooves on the base of the diamicton. (b) The diamicton and its texture, showing dispersed clasts and brecciation.

gular and subrounded clasts) and clast surface features (the presence of striated and faceted clasts). In addition, the slickensided, grooved and brecciated debris layer in iceberg KF07 provides strong evidence of subsole transport at the base of one of the tidewater glaciers. The matrix of the debris in the icebergs can be compared with data on modern fjordal sediments in Kongsfjorden. These typically show variable proportions of sand, silt and clay, with a tendency towards the finer of these fractions (Elverhøi and others, 1980; Boulton, 1990). Bennett and others (1999) have analyzed the particle size of matrix in fjord-bottom sediments raised in the thrust-moraine complexes on the margins of Kongsfjorden. These sediments were emplaced by the rapid advance of the Kronebreen/Kongsvegen tidewater glacier complex around 1948 and show a tendency for sandy matrices, in keeping with our particle-size determinations for the modern icebergs (Fig. 5).

Three main lines of evidence are present in the thin sections to indicate that the diamicton in iceberg KF07 has deformed:

(i) The pervasive flow-parallel aligned fabric of consistent orientation (and associated fractures), at $\sim 45^{\circ}$ to the slickensided surface. This suggests that the sediment has been subject to simple shear, but has not been subject to large cumulative strain.

(ii) "Galaxy" structures are common, which indicate rotation of larger grains within the matrix, typical of the deformable beds described by Van der Meer (1997).

(iii) Fractured grains, also indicative of a deforming bed as particles impact on one another (Hiemstra and Van der Meer, 1997).

The variably orientated fractures, which bear no relationship to earlier structures, are apparently extensional features resulting in void space in the sediment. The sediment, being dry when sampled, is believed to have cracked as a result of desiccation. Dry, freezing conditions since the sediment was exposed would have facilitated fracturing.

\section{The nature of the bed beneath the tidewater glaciers}

It is tempting to suggest that the sediment in the icebergs directly reflects the nature of the bed beneath the tidewater glaciers in Kongsfjorden. If this is the case, the sediment preserved in any individual iceberg represents a small snapshot of the glacier bed. So, for example, the slickensided and deformed till layer attached to iceberg KF07 might be taken to indicate rapid basal motion and pervasive deformation of a till layer beneath the tidewater glacier that calved the iceberg. In order for this inference to be correct, the sediment would have to survive unmodified during the calving process and then be protected from ablation until the iceberg became frozen into place within the sea ice. However, interpretation of the transport history of the subglacial sediment prior to the calving that produced the icebergs is complex, and the following alternative explanations and limitations must be borne in mind.

1. The iceberg sediment could have been entrained at the grounding line. The grounding line of many tidewater glaciers rests on a marine shoal, and these areas are possible locations for sediment deformation (Menzies, 2000). It is therefore possible that the sediment contained in the icebergs was entrained at or near to the terminus immediately prior to calving. If this is the case, then the iceberg debris demonstrates only late-stage deformation during calving and offers less insight into the processes of glacier motion further up-glacier. However, geophysical data suggest that the Kongsfjorden glaciers are not generally receding from marine shoals (Elverhøi and others, 1980).

2. Glacier beds are spatially and temporally heterogeneous. Even if the iceberg sediment does truly represent the nature of the glacier bed prior to iceberg calving, it is difficult to assess the overall extent of this type of rapid basal motion and deformation of a till layer. This is because it is possible that the sediment in the 12 icebergs sampled is not representative of basal conditions across the entire length or width of the glacier. Some areas of the bed may be deforming at any one time whilst others are not, or the processes of deformation may be temporally variable (Fischer and Clarke, 1997).

3. Individual icebergs contain only a small proportion of the glacier bed. The 12 icebergs sampled in Kongsfjorden represent a sample of approximately $30 \mathrm{~m}^{2}$ of the glacier bed. Icebergs in Kongsfjorden are produced by five tidewater glaciers with a combined width of $10 \mathrm{~km}$ and terminus flow speeds of up to $800 \mathrm{~m} \mathrm{a}^{-1}$. The 12 icebergs therefore represent only a small proportion of the total ice discharge of these glaciers in any given year. The icebergs sampled, however, contain high proportions of diagnostic clast lithologies, such as Carboniferous and Devonian sandstone (e.g. KF08 and KF11), which can be traced directly from the tidewater front of Kronebreen. This means that the icebergs can be related directly to a source glacier, thus 

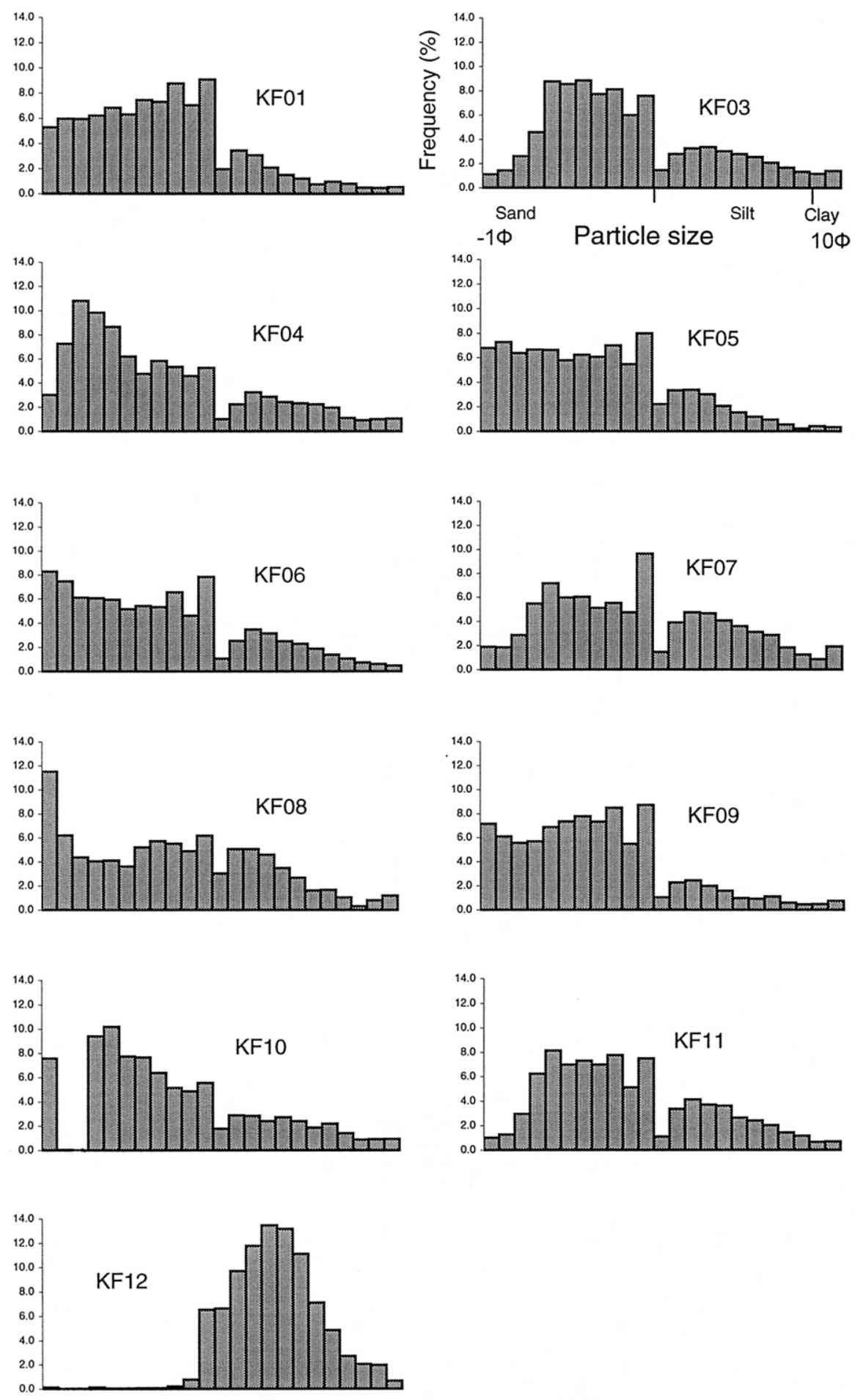

Fig. 5. Histograms showing particle-size data for the 11 debris-rich icebergs sampled in this study. Intervals are in half $\phi$. Samples KF01-KF11 are diamicton, whilst KF12 is mud.

increasing the proportion of the bed that they represent. However, if we are to regard their sedimentary characteristics as representative of an individual tidewater glacier, a large number of samples are required in order to establish with confidence the nature of the glacier bed. In the absence of this large sample population, the Kongsfjorden icebergs are best viewed as snapshots of the glacier bed.

\section{GONGLUSIONS}

1. Although an imperfect technique, the analysis of debris in icebergs provides information about the beds of tidewater glaciers where there is a paucity of information available by other means. The sampling of debris in icebergs provides a potentially valuable method of examining the otherwise inaccessible bed beneath tidewater glaciers, although care is required in making inferences about glacier dynamics from their sedimentary characteristics. This is because (a) calving processes at the grounding line can alter the sedimentary content of icebergs, and (b) there is no guarantee that individual icebergs are representative of the conditions beneath the entirety of the glaciers that calved them.

2. Debris layers in a sample of 12 debris-bearing icebergs in Kongsfjorden ranged from being entirely composed of sediment with no interstitial ice, through sharply 

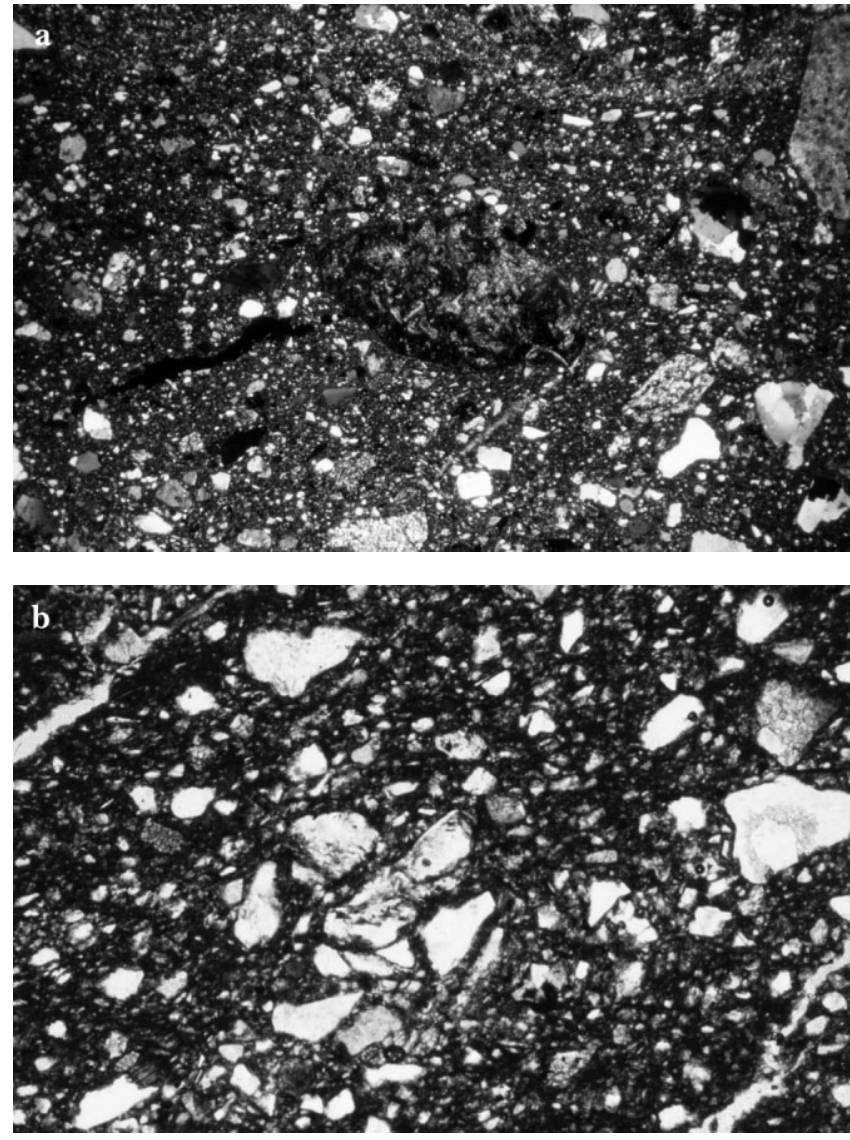

Fig. 6. Microstructures observed in thin sections of diamicton from iceberg KF07, interpreted as representing the presence of a deformable bed. Photomicrographs are taken from the flowparallel section, and both images show a field of view measuring 16 mm across. (a) Galaxy structure, comprising silt grains arranged around a small pebble (cross-polarized light). (b) Fractured clast, centre left of photograph (normal light).

defined, debris-rich ice layers, to ice layers in which the debris was sparsely disseminated. Folding on the submetre scale was also evident. The dominant sedimentary facies in the icebergs examined is a clast-rich muddy diamicton, although muddy gravel and mud were also present in some debris layers.

3. Sediment texture and clast-shape analyses show that the diamicton is of basal origin (basal till). The debris in one iceberg revealed a slickensided base, interpreted as the imprint of striations from the bed of the glacier or as an interface within the till. Micromorphological structures within the till indicate strong evidence of deformation.

4. This study represents a first step in using the sedimentary characteristics of iceberg debris to interpret subglacial conditions beneath tidewater glaciers. Although we recognize that large populations of icebergs are required in order to make meaningful inferences about tidewater glacier dynamics, this is a potentially promising avenue for future research.

\section{ACKNOWLEDGEMENTS}

This work was funded by a U.K. Natural Environment Research Council (NERG) grant (GST022192) under the ARCICE Thematic Programme. We thank N. Cox and B. Newham at the NERC Arctic Research Station in Ny-Ålesund for logistical support and safeguarding travel on sea ice, and J. Moore for use of the GPS system. B. P. Hubbard and two anonymous referees provided useful comments on an early draft of this paper. A. J. Maltman advised on the interpretation of microstructures in the thin sections of diamicton.

\section{REFERENGES}

Alley, R. B., D. D. Blankenship, C. R. Bentley and S.T. Rooney. 1986. Deformation of till beneath Ice Stream B, West Antarctica. Nature, 322(6074), 57-59.

Alley, R. B., D. D. Blankenship, C. R. Bentley and S. T. Rooney. 1987a. Till beneath Ice Stream B. 3. Till deformation: evidence and implications. 7 . Geophys. Res., 92(B9), 8921-8929.

Alley, R. B., D. D. Blankenship, S. T. Rooney and C. R. Bentley. 1987b. Till beneath Ice Stream B. 4. A coupled ice-till flow model. 7. Geophys. Res., 92(B9), 8931-8940.

Anandakrishnan, S., D. D. Blankenship, R. B. Alley and P. L. Stoffa. 1998. Influence of subglacial geology on the position of a West Antarctic ice stream from seismic observations. Nature, 394(6688), 62-65.

Ashley, G. M. and N. D. Smith. 2000. Marine sedimentation at a calving glacier margin. Geol. Soc. Am. Bull., 112 (5), 657-667.

Bell, R. E. and 6 others. 1998. Influence of subglacial geology on the onset of a West Antarctic ice stream from aerogeophysical observations. Nature, 394(6688), 58-62.

Benn, D. I. and C. K. Ballantyne. 1994. Reconstructing the transport history of glacigenic sediments: a new approach based on the co-variance of clast form indices. Sediment. Geol., 91 (1-4), 215-227.

Bennett, M. R., M. J. Hambrey and D. Huddart. 1997. Modification of clast shape in high-Arctic glacial environments. 7. Sediment. Res., 67, 550-559.

Bennett, M. R., M. J. Hambrey, D. Huddart, N. F. Glasser and K. R. Crawford. 1999. The landform and sediment assemblage produced by a tidewater glacier surge in Kongsfjorden, Svalbard. Quat. Sci. Rev., 18(2), 1213-1246.

Blankenship, D. D., C. R. Bentley, S. T. Rooney and R. B. Alley. 1986. Seismic measurements reveal a saturated porous layer beneath an active Antarctic ice stream. Nature, 322(6074), 54-57.

Boulton, G. S. 1990. Sedimentary and sea level changes during glacial cycles and their control on glacimarine facies architecture. In Dowdeswell, J. A. and J. D. Scourse, eds. Glacimarine environments: processes and sediments. London, Geological Society, 15-52. (Special Publication 53.).

Boulton, G. S. and R. C.A. Hindmarsh. 1987. Sediment deformation beneath glaciers: rheology and geological consequences. 7. Geophys. Res., 92(B9), 9059-9082.

Dowdeswell, J. A. and E. K. Dowdeswell. 1989. Debris in icebergs and rates of glaci-marine sedimentation: observations from Spitsbergen and a simple model. 7. Geol., $97(2), 221-231$.

Dowdeswell, J. A. and C. F. Forsberg. 1992. The size and frequency of icebergs and bergy bits derived from tidewater glaciers in Kongsfjorden, northwest Spitsbergen. Polar Res., 11 (2), 81-91.

Dowdeswell, J. A. and R. D. Powell. 1996. Submersible remotely operated vehicles $(\mathrm{ROV})$ for investigations of the glacier-ocean-sediment interface. F. Glaciol., $42(140)$, 176-183.

Elverhøi, A. 1984. Glacigenic and associated marine sediments in the Weddell Sea, fjords of Spitsbergen and the Barents Sea: a review. Mar. Geol., 57(1/4), 53-88.

Elverhøi, A., O. Liestøl and J. Nagy. 1980. Glacial erosion, sedimentation and microfauna in the inner part of Kongsfjorden, Spitsbergen. Nor. Polarinst. Skr., 172, 33-61.

Fischer, U. H. and G. K. C. Clarke. 1997. Stick-slip sliding behaviour at the base of a glacier. Ann. Glaciol., 24, 390-396.

Gades, A. M., C. F. Raymond, H. Conway and R.W. Jacobel. 2000. Bed properties of Siple Dome and adjacent ice streams, West Antarctica, inferred from radio-echo sounding measurements. F. Glaciol., 46(152), 88-94.

Hagen, J. O., O. Liestøl, E. Roland and T. Jørgensen. 1993. Glacier atlas of Svalbard and Jan Mayen. Nor. Polarinst. Medd. 129.

Hambrey, M. J. 1994. Glacial environments. London, University College Press. Harland, W. B. 1997. The geology of Svalbard. London, The Geological Society. (Memoir 17.)

Hiemstra, J. F. and J. J. M. van der Meer. 1997. Pore-water controlled grain fracturing as an indicator for subglacial shearing in tills. f. Glaciol., 43(145), 446-454.

Hjelle, A. 1993. Geology of Svalbard. Nor. Polarinst. Polarhåndbok 7.

Hunter, L. E., R. D. Powell and D. E. Lawson. 1996. Flux of debris transported by ice at three Alaskan tidewater glaciers. f. Glaciol., 42(140), $123-135$.

Ito, H. and S. Kudoh. 1997. Characteristics of water in Kongsfjorden, Svalbard. Proc. NIPR Symp. Polar Meteorol. Glaciol. 11, 253. 
Iverson, N. R., T. S. Hooyer and R. LeB. Hooke. 1996. A laboratory study of sediment deformation: stress heterogeneity and grain-size evolution. Ann. Glaciol., 22, 167-175.

Iverson, N. R., R.W. Baker and T. S. Hooyer. 1997. A ring-shear device for the study of till deformation: tests on tills with contrasting clay contents. Quat. Sci. Rev., 16(9), 1057-1066.

Iverson, N. R., T. S. Hooyer and R. W. Baker. 1998. Ring-shear studies of till deformation: Coulomb-plastic behavior and distributed strain in glacier beds. F. Glaciol., 44(148), 634-642.

Kamb, B. 1991. Rheological nonlinearity and flow instability in the deforming bed mechanism of ice stream motion. f. Geophys. Res., 96(B10), 16,585-16,595.

Lefauconnier, B., J. O. Hagen and J.-P. Rudant. 1994. Flow speed and calving rate of Kongsbreen glacier, Svalbard, using SPOT images. Polar Res., 13(1), 59-65.

Melvold, K. 1992. Studie av brebevegelse på Kongsvegen og Kronebreen, Svalbard. Oslo, Universitetet i Oslo. (Rapportserie i Naturgeografi 1.)

Menzies, J. 2000. Microstructures in diamictites of the Lower Gowganda Formation (Huronian), near Lake Elliot, Ontario; evidence for deform- ing-bed conditions at the grounding line? 7. Sediment. Res., 70(1), 210-216. Moncrieff, A. C. M. 1989. Classification of poorly sorted sedimentary rocks. Sediment. Geol., 65(1-2), 191-194.

Powell, R. D. and B. F. Molnia. 1989. Glacimarine sedimentary processes, facies and morphology of the south-southeast Alaska Shelf and fjords. Mar. Geol., 85(2/4), 359-390.

Powers, M. C. 1953. A new roundness scale for sedimentary particles. f. Sediment. Petrol., 23(2), 117-119.

Tulaczyk, S., B. Kamb, R. P. Scherer and H. F. Engelhardt. 1998. Sedimentary processes at the base of the West Antarctic ice stream: constraints from textural and compositional properties of subglacial debris. F. Sediment. Res., 68(3A), 487-496.

Van der Meer, J. J. M. 1997. Particle and aggregate mobility in till: microscopic evidence of subglacial processes. Quat. Sci. Rev., 16(8), 827-831.

Van der Wateren, F. M. 1998. Structural analysis of micro- and macro-fabrics in tills - kinematic indicators of subglacial shearing. Workshop on Glacial Debris Transport and Deposition: Processes and Products, University of Leeds, 9-11 January 1998. Leeds, University of Leeds. School of Geography.

MS received 24 May 2000 and accepted in revised form 23 February 2001 